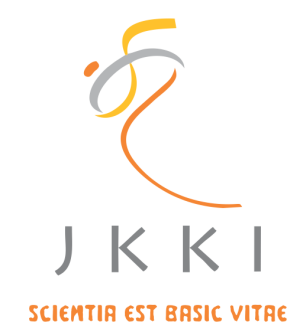

Jurnal Kedokteran dan Kesehatan Indonesia

Indonesian Journal of Medicine and Health

Journal homepage: https://journal.uii.ac.id/JKKI

\title{
Influence of obesity to Covid-19
}

Asri Hendrawati*1

${ }^{1}$ Department of Biochemistry, Faculty of Medicine, Universitas Islam Indonesia, Yogyakarta, Indonesia

\section{\begin{tabular}{ll}
\hline & E \\
\hline ART ICLE INF O \\
*Corresponding author: \\
097110416@uii.ac.id
\end{tabular}}

DOI: 10.20885/JKKI.Vol12.Iss1.art2 Copyright @2021 Authors. This is an open access article distributed under the terms of the Creative Commons Attribution-NonCommercial $\quad 4.0$ International Licence (http:// creativecommons.org/licences/ by-nc/4.0/).

\section{EDIT ORIAL}

n January 2020, WHO announced that epidemy of Corona Virus called COVID-19 has occurred. ${ }^{1}$ Today, the COVID-19 has become a pandemic and an infectious disease that harms humans. Some factors aggravating a condition of COVID-19 patients have been overserved, for example: age, gender and comorbidity. One of factors aggravating the COVID-19 is overweight and obesity. Obesity is also considered as a factor aggravating symptoms of H1N1 virus. ${ }^{2}$

Some theories about overweight or obesity that aggravate the COVID-19 appear. In obese patients, mediators of inflammation that decrease compounds of anti-inflammation such adiponectin and increase oxidative stress occur. The increase of oxidative stress contributes for decreased ability of cell immune to fight for the infection. ${ }^{3}$ Obesity also can increase thrombosis causing disseminated intravascular coagulation (DIC) and thrombosis vena. ${ }^{4}$ Thrombosis also occurs in blood vessels in the lungs that can decrease the volume and capacity of the lung functions; consequently, this can complicate the clinical condition of COVID-19 patients. ${ }^{5}$ Increases of fat tissue in obesity can produce leptin which interferes heart functions and causes atherosclerosis. These conditions can aggravate the COVID-19 and increase mortality of COVID-19 patients. $^{6}$

A main factor of death in COVID-19 patients is that fibrosis occurs in the lungs. In obese patients, there is an increase in lipofibroblasts in lung tissue containing fatty granules that cause fat deposits in the lungs. If the lungs are infected, lipofibroblast will be tuned into myofibroblast causing pulmonary fibrosis. ${ }^{7}$ Obese patients also often experience complications such as glucose metabolism disorders that cause hyperglycaemia. Hyperglycaemia can cause fluid and electrolyte disorders, blood coagulation problems, and aggravating infectious process. These will complicate the condition of COVID-19 patients. ${ }^{8}$

Based on the discussion above, we should have efforts to maintain an ideal weight and lose weight for the overweight and obesity. However, the efforts will be difficult because the pandemic situation contributes for stress that can cause appetite in certain people to increase. In addition, the current situation requires us to do work from home that causes fewer physical activities and becomes a risk factor of overweight. Therefore, we must maintain a diet and exercise at home. ${ }^{9}$

\section{REFERENCES}

1. Cai Q, Chen F, Wang T, Luo F, Liu X, Wu Q, et al. Obesity and COVID-19 severity in a designated hospital in Shenzhen, China. Diabetes Care. 2020;43(7):1392-8.

2. Caci G, Albini A, Malerba M, Noonan DM, Pochetti P, Polosa R. COVID-19 and obesity: Dangerous liaisons. Journal of Clinical Medicine. 2020;9(8):2511.

3. Ellulu MS, Patimah I, Khaza H, Rahmat A, Abed Y, Sci AM. Obesity and inflammation : The linking mechanism and the complications. Archives of Medical Science. 2016;13(4): 851-63. 
4. Sattar N, McInnes IB, McMurray JJV. Obesity is a risk factor for severe COVID-19 infection: Multiple potential mechanisms. Circulation. 2020;142:4-6.

5. Lockhart SM, O'Rahilly S. When two pandemics meet: Why is obesity associated with increased COVID-19 mortality? Medicine. 2020;1(1):33-42.

6. Petrakis D, Margină D, Tsarouhas K, Tekos F, Stan M, Nikitovic D, et al. Obesity - a risk factor for increased COVID-19 prevalence, severity and lethality (Review). Molecular Medicine Reports. 2020;22(1):9-19.

7. Zhu X, Yang L, Huang K. Covid-19 and obesity: Epidemiology, pathogenesis and treatment. Diabetes, Metabolic Syndrome and Obesity: Targets and Therapy. 2020;13:4953-9.

8. Butler SO, Btaiche IF, Alaniz C. Relationship between hyperglycemia and infection in critically ill patients. Pharmacotherapy. 2005;25(7):963-76.

9. Abbas AM, Fathy SK, Fawzy AT, Salem AS, Shawky MS. The mutual effects of COVID-19 and obesity. Obesity Medicine. 2020;19. 